\title{
The Metabolism of Formic Acid by Sarcina ventriculi
}

\author{
By T. BAUCHOP \\ National Centre for Primate Biology, University of California, \\ Davis, California, 95616. U.S.A. \\ AND E. A. DAWES \\ Department of Biochemistry, The University of Hull \\ (Accepted for publication 7 December 1967) \\ SUMMARY
}

\begin{abstract}
Sarcina ventriculi possesses a hydrogen-producing mechanism similar to that present in the coli-aerogenes group of bacteria. Formate is converted to hydrogen and carbon dioxide by formate hydrogenlyase and $S$. ventriculi is thus the only organism outside the coliform group known to possess this system. Formate dehydrogenase has also been demonstrated in the intact $S$. ventriculi organisms with both methylene blue and benzylviologen as hydrogen acceptors, but with extracts activity was only observed with benzylviologen. Hydrogenase activity was present in whole organisms and extracts of $S$. ventriculi. Hydrogenlyase, hydrogenase and, to a lesser extent, formate dehydrogenase activities in $S$. ventriculi are extremely sensitive to inhibition by oxygen. It is important support for the postulated mechanism of action of formate hydrogenlyase in the coliform bacteria that $S$. ventriculi also possesses the enzymic components deemed necessary for this activity, namely formate dehydrogenase (benzylviologen) and hydrogenase.
\end{abstract}

\section{INTRODUCTION}

The occurrence of a gastric fermentation caused by a sarcina was first recorded in 1842 by John Goodsir, an Edinburgh Surgeon, who proposed the name Sarcina ventriculi for the organism which he found in the gastric fluid of one of his patients. Although $S$. ventriculi subsequently was widely reported in the nineteenth century, early workers failed to cultivate the organism in artificial media. Falkenheim (1885) caused considerable confusion in the literature by describing easily grown aerobic sarcinas as $S$. ventriculi. This error was perpetuated by a number of workers and became accepted in the literature of microbiology by its incorporation in standard reference works (Bergey's Manual of Determinative Bacteriology, 1923-39; Topley and Wilson's Principles of Bacteriology and Immunity, Ist to 4th eds., 1929-55). Beijerinck (1905), during a series of soil enrichment experiments, was surprised to find $S$. ventriculi in certain of his cultures. This was the first isolation of the organism in pure culture and his work demonstrated the conditions necessary for the growth of $S$. ventriculi. Enrichment from soil was obtained under anaerobic conditions in a complex glucosecontaining medium at acid $\mathrm{pH}$. In I9I I Beijerinck succeeded in isolating $S$. ventriculi from the human stomach and was able to show that the gastric form was identical with that found in soil. Later, the organism was extensively studied by Smit (1930) who found that ethanol and carbon dioxide, together with smaller amounts of acetate and hydrogen, were the major products of glucose fermentation. Kluyver (I93I) also 
published a fermentation balance for $S$. ventriculi which agreed closely with the results of Smit. Milhaud, Aubert \& van Niel (1956) showed that glucose was fermented by the Embden-Meyerhof route, while Bauchop \& Dawes (1959) and Arbuthnott, Bauchop \& Dawes (1960) produced evidence that the terminal fermentation mechanism in $S$. ventriculi consisted of a unique combination of two pathways of pyruvate catabolism, namely a yeast-type pyruvate decarboxylase and a coliform-like thioclastic fission of pyruvate. These reaction mechanisms adequately accounted for the fermentation products previously reported. The present report concerns the mechanism of hydrogen formation in $S$. ventriculi.

\section{METHODS}

Organism. Sarcina ventriculi was isolated from garden soil. Approximately 2 g. soil were placed in a $250 \mathrm{ml}$. Erlenmeyer flask filled with medium A; the flask was plugged with cotton-wool and incubated at $37^{\circ}$. After $16-20 \mathrm{hr}$ a vigorous fermentation began and large numbers of sarcinas were present. The contents of the flask were stirred and Io ml. inoculated into a second flask containing $200 \mathrm{ml}$. medium A which had been freshly boiled and cooled. This transfer procedure was repeated three or four times until $S$. ventriculi was established in pure culture. Inoculation from this culture into sterile medium $\mathrm{N}$ then enabled the pure culture to be maintained at $\mathrm{pH} 7 \cdot 0$.

Media. Medium $A$ (for isolation). $2 \%$ (w/v) glucose; I \% (w/v) Bacto-peptone (Difco); I \% (w/v) yeast extract (Difco); $0.3 \%$ (v/v) conc. $\mathrm{HCl}$. This medium was used without sterilization.

Medium $N$. Where bacteria were required for biochemical studies the above medium was used with the omission of $\mathrm{HCl}$. This medium as made up was at $\mathrm{pH} 7 \cdot 0$ and no adjustment was made. The glucose was prepared as a separate solution and added to the remainder of the medium after each portion had been sterilized and cooled.

Conditions of growth. Volumes $(400 \mathrm{ml}$.) of medium N were dispensed into $500 \mathrm{ml}$. Erlenmeyer flasks which were plugged and sterilized by autoclaving at $120^{\circ}$ for $15 \mathrm{~min}$. When inoculation was to be done immediately, the flask was removed from the autoclave, cooled quickly and given an inoculum $(5 \%, v / v)$ of actively fermenting culture. When the medium had been stored for some time before use, it was boiled for a few minutes and cooled immediately before inoculation. Removal of oxygen from the medium was an essential condition for growth. Sarcina ventriculi was cultivated at $37^{\circ}$. In some experiments larger amounts of bacteria were obtained by scaling up the above procedures to 5 or 101 . batches.

Harvesting of bacteria. This was simplified by the fact that Sarcina ventriculi grew as a sediment at the bottom of the culture vessel, which allowed most of the medium to be decanted and the bacteria to be collected by centrifuging the small volume which remained. In biochemical studies only actively fermenting bacteria were used. When large cultures (5 or 101.) were grown. the bulk of the medium was syphoned off and the bacteria obtained in a small volume which could be conveniently handled on the centrifuge.

Preparation of active washed bacterial suspensions. During the growth of Sarcina ventriculi large volumes of gas were produced. However, preliminary experiments to study the metabolism of glucose, pyruvate and formate by washed bacterial suspensions failed to show gas production. When bacterial suspensions were pipetted from the culture flask directly into Warburg flasks and incubated under $\mathrm{N}_{2}$, it was found that $\mathrm{H}_{2}$ and $\mathrm{CO}_{2}$ were produced by $S$. ventriculi during glucose fermentation. It was sub- 
sequently discovered that active washed bacterial suspensions could be obtained when precautions were taken to protect these preparations from atmospheric oxygen.

To obtain consistently active washed bacterial suspensions the following procedures were used. Warburg flasks were prepared with all additions except buffer solution and bacterial suspension, the side-arms stoppered and the manometer joints greased. With an actively fermenting culture the medium was decanted as previously described. The bacterial suspension remaining (20-30 $\mathrm{ml}$.) was made up to $80 \mathrm{ml}$. with freshly boiled and quickly cooled distilled water. This suspension was transferred immediately to a centrifuge tube and centrifuged at $1500 \mathrm{~g}$ for $2 \mathrm{~min}$. During the centrifugation procedure some of the buffer to be used was boiled and quickly cooled, and the appropriate quantities pipetted into Warburg flasks. By this time the centrifuge had stopped and the bacteria were taken up in $10 \mathrm{ml}$. oxygen-free buffer solution. This bacterial suspension was pipetted into the Warburg flasks, which were quickly attached to manometers and gassed with $\mathrm{N}_{2}$ for $4 \mathrm{~min}$. This procedure enabled active washed bacterial preparations to be obtained consistently. Usually small amounts of glucose were carried over, because of insufficient washing; the fermentation of this glucose was allowed to proceed to completion before substrates were added. This procedure was preferable to further washing of the bacteria with possible loss of activity.

Cell-free extracts. These were prepared by grinding bacteria with powdered glass (Utter \& Werkman, 1942).

Protein nitrogen was determined by the method of Stickland (195I).

Manometric methods. Standard manometric techniques were used. All experiments were done at $37.5^{\circ}$. The rate of shaking was I IO-120 cyc./min.

Viologen dyes. Methylviologen was obtained from Jacobsen Van Den Berg and Co. (73 Cheapside, London, E.C. 2) and benzylviologen from British Drug Houses Ltd.

Powdered glass. This was purchased from Canadian Laboratory Supplies (8655 Delmeade Road, Mount Royal Box 2090, Station 'O', Province of Quebec, Canada) and was Pyrex glass powder passed through a 200-mesh sieve.

\section{RESULTS}

\section{Formate hydrogenlyase}

Washed suspensions of Sarcina ventriculi metabolized formate to equimolar amounts of $\mathrm{H}_{2}$ and $\mathrm{CO}_{2}$ (Fig. I), indicative of the classical hydrogenlyase reaction. Initially the ratio of gases evolved in the absence and presence of alkali was not 2:I, presumably because the initial reaction occurred too rapidly for the $\mathrm{CO}_{2}$ evolved to be absorbed by the alkali in the centre-well. As the reaction rate decreased the ratio approached 2:I.

The evolution of hydrogen from formate by whole organisms of Sarcina ventriculi had a broad $\mathrm{pH}$ optimum in the range $\mathrm{pH} 5^{\circ} 0-7^{\circ} 0$, but activity fell to low levels at $\mathrm{pH} 4.0$ and 8.0 . The $\mathrm{pH}$ optimum of formate hydrogenlyase in whole Escherichia coli organisms was $7 \cdot 0$ (Stephenson \& Stickland, 1932).

The evolution of hydrogen was sensitive to the inhibitors of the classical hydrogenlyase system (Table I). Nitrate and nitrite were inhibitory, also extremely low concentrations of cyanide. Inhibition by somewhat higher concentrations of formaldehyde and sensitivity to oxygen and carbon monoxide were also typical of both the Sarcina ventriculi and Escherichia coli formate hydrogenlyase systems.

The effect of an atmosphere of hydrogen on hydrogen evolution from formate by 
Sarcina ventriculi appeared to constitute an important difference from the Escherichia coli system. Stephenson \& Stickland (1932) obtained $50 \%$ inhibition of hydrogen evolution with $E$. coli under these conditions; with $S$. ventriculi an atmosphere of hydrogen produced only $5 \%$ inhibition. The $50 \%$ inhibition observed with $E$. coli was attributed to reversal of the reaction with $\mathrm{H}_{2}$ and dissolved $\mathrm{CO}_{2}$ under the test conditions (Woods, 1936). However, under similar conditions it appears that acid produced from residual glucose in the Sarcina ventriculi suspensions causes rapid removal of the $\mathrm{CO}_{2}$ which is essential for reversing the reaction, and consequently the inhibition observed under $\mathrm{H}_{2}$ is slight (Table $\mathrm{I}$ ).

\section{Table I. Inhibition of formate hydrogenlyase of $S$. ventriculi}

The system contained $20 \mu$ moles of sodium formate (side arm); inhibitors at concentrations indicated; I05 $\mu$ moles of potassium phosphate; II-I7 mg. (dry weight) of cells; pH 5.0; total volume $2.8 \mathrm{ml}$.; $0.2 \mathrm{ml}$. of $20 \%(\mathrm{w} / \mathrm{v}) \mathrm{KOH}$ in the centre-well; atmosphere $\mathrm{N}_{2}$; temperature $37^{\circ}$. For inhibition with $\mathrm{H}_{2}$ the $\mathrm{pH}$ was $7 \cdot 0$. For inhibition with $\mathrm{CO}$, Warburg flasks were first flushed with $\mathrm{N}_{2}$, then flushed with $\mathrm{CO}$ for $5 \mathrm{~min}$. In the experiments with $\mathrm{CO}$, flasks were enclosed in opaque bags to prevent possible photo-dissociation of CO-Fe complexes.

\begin{tabular}{|c|c|c|c|c|}
\hline \multirow[b]{2}{*}{ Inhibitor } & \multirow{2}{*}{$\begin{array}{l}\text { Inhibitor } \\
\text { concentration } \\
\text { (mM) }\end{array}$} & \multicolumn{2}{|c|}{$\mathbf{H}_{2}$ produced $(\mu \mathrm{l} . / \mathrm{hr} . / \mathrm{mg}$. dry wt) } & \multirow{2}{*}{$\begin{array}{c}\text { Inhibition } \\
(\%)\end{array}$} \\
\hline & & Control & Inhibitor & \\
\hline $\mathrm{NaNO}_{3}$ & $I \cdot O$ & 60 & 22 & 63 \\
\hline $\mathrm{NaNO}_{2}$ & $1 \cdot 0$ & 60 & 14 & 76 \\
\hline $\mathrm{KCN}$ & 0.005 & 185 & 93 & 50 \\
\hline $\mathrm{KCN}$ & 0.05 & 185 & 0 & 100 \\
\hline HCHO & $1 \cdot 0$ & 222 & I 86 & 16 \\
\hline HCHO & $80 \cdot 0$ & 222 & 30 & 86 \\
\hline $\mathbf{H}_{2}$ & $100 \%$ & 240 & 228 & 5 \\
\hline $\mathrm{O}_{2}$ & $20 \%$ & no spec & eriment & 100 \\
\hline $\mathrm{CO}$ & $100 \%$ & 104 & 0 & 100 \\
\hline
\end{tabular}

Reversibility of the hydrogenlyase reaction was demonstrated by the inclusion of bicarbonate in the reaction mixture to neutralize the acid formed from residual glucose; the presence of hydrogen was essential for gas utilization to occur (Fig. 2).

The extreme sensitivity to inhibition by oxygen of the Sarcina ventriculi formate hydrogenlyase prevented the demonstration of activity in cell-free extracts. Glutathione and cysteine did not restore activity either to oxygen-inhibited washed suspensions or to extracts of $S$. ventriculi.

Stephenson \& Stickland (1932), Yudkin (1932) and Pinsky \& Stokes (1952) all found that oxygen had little effect on the preformed hydrogenlyase system in whole Escherichia coli organisms. In direct contrast, Lascelles (1948) found that hydrogenlyase activity of $E$. coli was strongly depressed by exposure to oxygen. The demonstration of hydrogenlyase activity in extracts of $E$. coli presented difficulties in the early work of Gest \& Gibbs (1952). Later, active preparations were apparently more easily obtainable (Gest \& Peck, 1955; Peck \& Gest, 1957a). More recently Pichinoty (1962) found that hydrogenlyase in extracts of $E$. coli was inactivated irreversibly by contact with air.

\section{Formate dehydrogenase}

Escherichia coli possesses two types of formate dehydrogenase activity, with methylene blue and benzylviologen as the respective hydrogen acceptors. If grown with vigorous aeration, the organism displayed no hydrogenlyase activity but formate 
dehydrogenase (methylene blue) was present (Stickland, 1929; Gale, 1939). However, Gest \& Peck (1955) showed that benzylviologen can act as acceptor in the formate dehydrogenase system with extracts of E. coli. These authors and Peck \& Gest (1957a) also demonstrated that the presence of formate dehydrogenase (benzylviologen) was essential for hydrogenlyase activity.

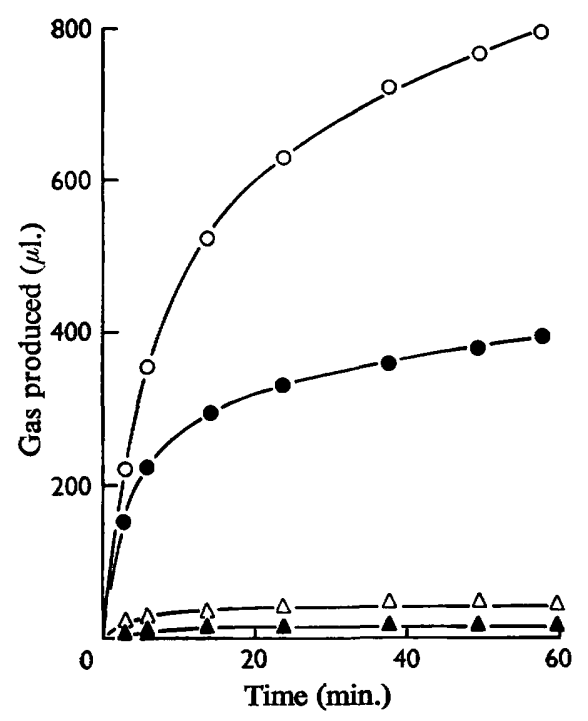

Fig. I

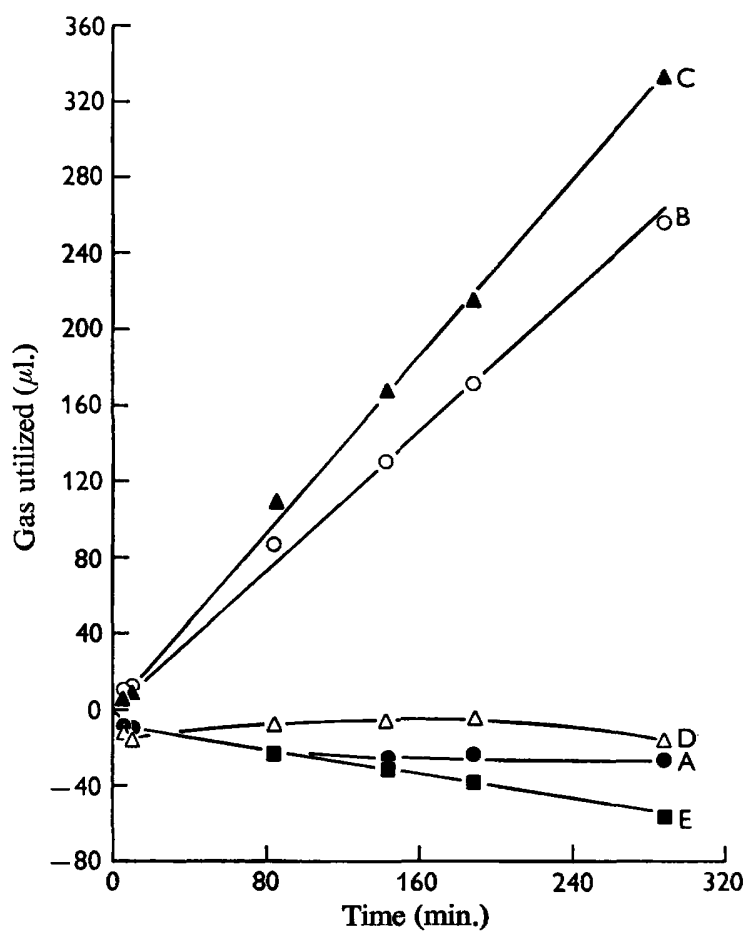

Fig. 2

Fig. I. Formate hydrogenlyase of S. ventriculi. Warburg flasks contained: $20 \mu$ moles of sodium formate (side arm); $57.5 \mu$ moles of potassium phosphate; I I mg. (dry wt) of cells; pH 5.0 ; total volume $2.8 \mathrm{ml}$.; $0.2 \mathrm{ml}$. of $20 \%(\mathrm{w} / \mathrm{v}) \mathrm{KOH}$ in the centre-well of the Warburg flasks where indicated; atmosphere $\mathrm{N}_{2} . \mathrm{H}_{2}+\mathrm{CO}_{2}$ evolution, $\mathrm{O} ; \mathrm{H}_{2}$ evolution, ; endogenous $\mathrm{H}_{2}+\mathrm{CO}_{2}, \triangle$; endogenous $\mathrm{H}_{2}, \Delta$.

Fig. 2. Reversibility of formate hydrogenlyase in whole cells of $S$. ventriculi. Warburg flasks contained in the main compartment $67 \mu$ moles of either potassium phosphate or $\mathrm{NaHCO}_{3}$, and $16 \mathrm{mg}$. (dry wt) of cells; side arms contained either water or $25 \mu$ moles of $\mathrm{NaHCO}_{3}$; total volume $2.8 \mathrm{ml}$., atmosphere, $\mathrm{H}_{2}$ or $\mathrm{N}_{2}$ as indicated. All flasks were flushed with $\mathrm{H}_{2}$ for $5 \mathrm{~min}$. Flasks $\mathrm{D}$ and $\mathrm{E}$ were then flushed with $\mathrm{N}_{2}$ for $5 \mathrm{~min}$. Zero time readings were taken immediately and then, where applicable, $\mathrm{NaHCO}_{3}$ was tipped from the side arms. $\mathrm{A}, 67 \mu$ moles of phosphate buffer, $\mathrm{pH} 7.4$ (main vessel), $\mathrm{NaHCO}_{3}$ absent, $\mathrm{H}_{2}, 9 ; \mathrm{B}, 67 \mu$ moles of $\mathrm{NaHCO}_{3}$ (main vessel), $\mathrm{H}_{2}, \mathrm{O} ; \mathrm{C}, 67 \mu$ moles of $\mathrm{NaHCO}_{3}$ (main vessel), $25 \mu$ moles of $\mathrm{NaHCO}_{3}$ (side arm), $\mathrm{H}_{2}, \triangle ; \mathrm{D}, 67 \mu$ moles of $\mathrm{NaHCO}_{3}$ (main vessel), $\mathrm{N}_{2}, \triangle ; \mathrm{E}, 67 \mu$ moles of $\mathrm{NaHCO}_{3}$ (main vessel), $25 \mu$ moles of $\mathrm{NaHCO}_{3}$ (side arm), $\mathrm{N}_{2}$, $\mathbf{}$.

Washed suspensions of Sarcina ventriculi possessed formate dehydrogenase activity with methylene blue (Table 2). When the bacteria were thoroughly washed, hydrogenlyase was characteristically absent, although high formate dehydrogenase activity remained. Formate dehydrogenase activity has also been successfully demonstrated in whole $S$. ventriculi organisms with benzylviologen as acceptor (Table 2). It was note- 


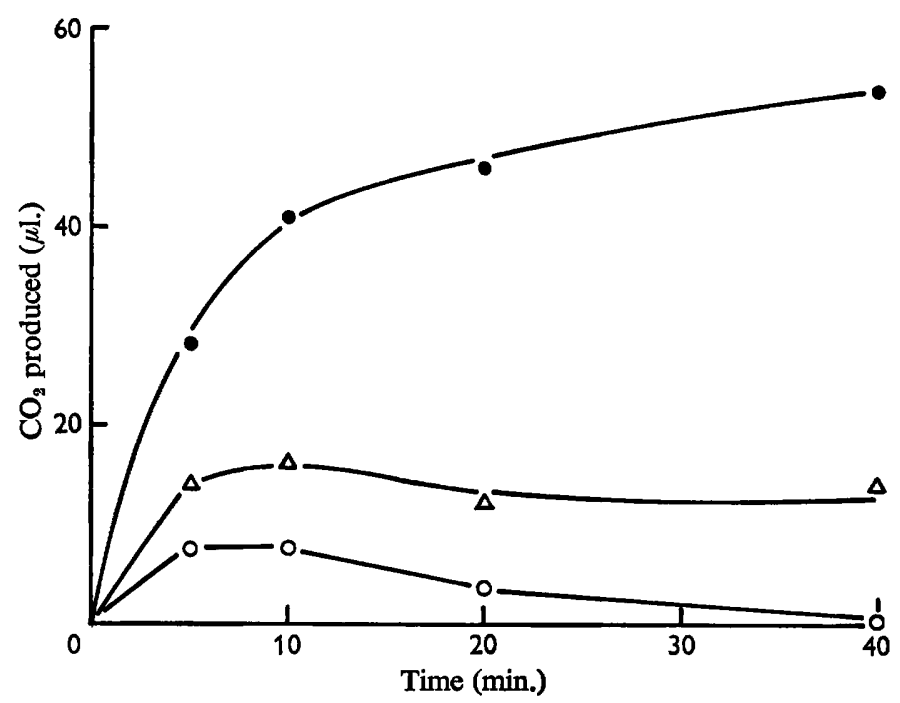

Fig. 3. Formate dehydrogenase (benzylviologen) in extracts of $S$. ventriculi. Cell-free extracts were prepared by grinding with powdered glass. Warburg flasks contained: $20 \mu$ moles of sodium formate (side arm); $40 \mu$ moles of potassium phosphate; $20 \mu$ moles of benzylviologen; $1.0 \mathrm{ml}$. extract (0.35 mg. $\mathrm{N} / \mathrm{ml}$.); $\mathrm{pH} 7.0$; total volume $3.0 \mathrm{ml}$.; atmosphere $\mathrm{N}_{2}$. Benzylviologen, $\odot$; benzylviologen absent, $O$; endogenous with benzylviologen, $\triangle$.

\section{Table 2. Formate dehydrogenase activities of S. ventriculi with} methylene blue and benzylviologen as acceptors

Harvested cells were washed twice with distilled water and resuspended in water. Warburg flasks contained: $100 \mu$ moles of sodium formate (side arm); $40 \mu$ moles of potassium phosphate; $14 \mathrm{mg}$. (dry wt) of cells; $20 \mu$ moles of methylene blue or benzylviologen; $\mathrm{pH} 6.0$; total volume $3 \cdot 0 \mathrm{ml}$; ; atmosphere $\mathrm{N}_{2}$. Sodium formate was omitted for measurement of endogenous dye reduction.

\begin{tabular}{|c|c|c|c|c|c|c|}
\hline \multirow[b]{3}{*}{ Time (min.) } & \multicolumn{5}{|c|}{$\mathrm{CO}_{2}$ produced $(\mu 1)}$. & \\
\hline & \multicolumn{3}{|c|}{ Methylene blue } & \multicolumn{3}{|c|}{ Benzylviologen } \\
\hline & $\begin{array}{l}\text { Endogenous } \\
\text { with dye }\end{array}$ & Dye absent & Dye present & $\begin{array}{l}\text { Endogenous } \\
\text { with dye }\end{array}$ & Dye absent & Dye present \\
\hline $\begin{array}{l}3 \\
6\end{array}$ & $\begin{array}{l}7 \\
8\end{array}$ & $\begin{array}{l}15 \\
15\end{array}$ & $\begin{array}{l}180 \\
278\end{array}$ & 5 & $\begin{array}{l}5 \\
2\end{array}$ & $\begin{array}{l}30 \\
45\end{array}$ \\
\hline 12 & I0 & 17 & 315 & - & - & - \\
\hline 15 & - & - & - & 6 & $\mathbf{I}$ & 64 \\
\hline 24 & 18 & 25 & 343 & - & - & - \\
\hline 40 & - & - & - & 7 & I & 115 \\
\hline 60 & - & - & - & 8 & 5 & 135 \\
\hline
\end{tabular}

worthy that these cells were devoid of hydrogenlyase activity although formate dehydrogenase (benzylviologen) was still present. With extracts of $S$. ventriculi prepared by grinding with powdered glass, formate dehydrogenase was not detected with methylene blue as acceptor although activity was found with benzylviologen (Fig. 3). At $\mathrm{pH} 7 \cdot 0$, although only low activity was obtained as measured by $\mathrm{CO}_{2}$ evolution, the benzylviologen was strongly reduced only in the presence of formate. Again hydrogenlyase activity was absent from these preparations. 


\section{Hydrogenase}

Sarcina ventriculi, harvested and transferred to Warburg flasks with anaerobic precautions, possessed hydrogenase activity with methylene blue as hydrogen acceptor. Low activity was also observed with benzylviologen (Fig. 4). Both activities were increased by sodium dithionite. In experiments with the hydrogenase of Clostridium butylicum in cell-free extracts, Peck \& Gest (1957b) found that an induction period preceded reduction of benzylviologen; this induction period was eliminated in the presence of small amounts of sodium dithionite.

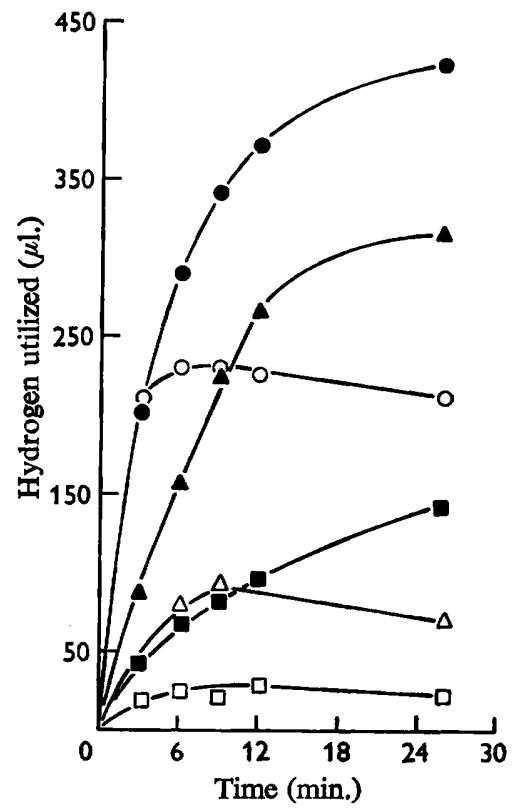

Fig. 4

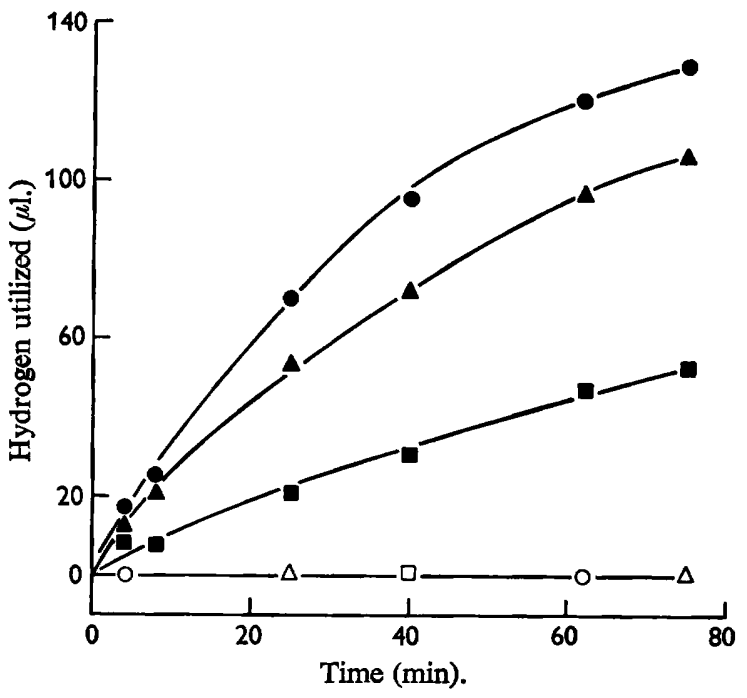

Fig. 5

Fig. 4. Hydrogenase of $S$. ventriculi. Warburg flasks contained: $20 \mu$ moles of dye (side arm); $90 \mu$ moles of potassium phosphate; $15 \mathrm{mg}$. (dry wt) of cells; $5 \mu$ moles of sodium dithionite where indicated; $\mathrm{pH} \mathrm{7.5;0.2} \mathrm{ml.} \mathrm{of} 20 \%(\mathrm{w} / \mathrm{v}) \mathrm{KOH}$ in the centre-well; total volume $3.0 \mathrm{ml}$; atmosphere $\mathrm{H}_{2}$. Dyes used were methylene blue (MB), benzylviologen (BV) and methylviologen (MV). Control flasks with boiled cells possessed no activity. MB, O; MB + dithionite, - ; BV, $\triangle$; BV+dithionite, $\Delta ; \mathrm{MV}, \square ; \mathrm{MV}+$ dithionite, $\mathbf{\square}$.

Fig. 5. Hydrogenase in cell-free extracts of $S$. ventriculi. Details as for Fig. 4 except that cell extract ( $0.4 \mathrm{mg}$. N/flask) replaced the whole cell suspension. Boiled extract possessed no activity. MB, O; MB + dithionite, - $\mathrm{BV}, \triangle$; $\mathrm{BV}+$ dithionite, $\Delta ; \mathrm{MV}, \square ; \mathrm{MV}+$ dithionite, $\mathbf{\square .}$

When Sarcina ventriculi organisms were washed thoroughly with distilled water, hydrogenase activity with benzylviologen or methylviologen was not obtained unless dithionite was present. With methylene blue high activity was obtained only in the presence of dithionite, whereas in its absence low activity was obtained and only after a lag period.

Extracts of Sarcina ventriculi were devoid of hydrogenase activity with any of the redox dyes tested. However, activity was restored to these preparations by the addition of small amounts of dithionite (Fig. 5). This is in agreement with the results of Fisher, 
Krasna \& Rittenberg (1954) who showed with the Escherichia coli system that oxygen inhibited hydrogenase by oxidation and reversible oxygenation. By using the evolution assay of Peck \& Gest (1956) attempts to show hydrogenase activity in whole organisms and extracts of $S$. ventriculi were unsuccessful.

\section{DISCUSSION}

The present results show that Sarcina ventriculi possesses a mechanism for the production of hydrogen essentially similar to that found in the coli-aerogenes group of bacteria. This system involves the production of formate from pyruvate, followed by the catabolism of formate to $\mathrm{H}_{2}$ and $\mathrm{CO}_{2}$. The enzymic activities shown in other organisms to be associated with the formate pathway of hydrogen production, namely hydrogenlyase, formate dehydrogenase and hydrogenase, are all present in $S$. ventriculi.

Inhibition of hydrogenlyase by oxygen is known to occur in other organisms, but the extreme sensitivity of the Sarcina ventriculi system would seem to be particularly noteworthy. Unless adequate precautions are taken to prevent exposure to air, the hydrogenlyase of $S$. ventriculi is irreversibly inhibited, even in whole organisms. With cell extracts, presumably due to similar inactivation, hydrogenlyase activity could not be demonstrated. Reducing agents were ineffective in annulling this inhibition both with whole organisms and with extracts.

Formate dehydrogenase activity was more stable than hydrogenlyase activity and conditions which inactivated hydrogenlyase did not affect formate dehydrogenase (benzylviologen) in intact organisms. The dehydrogenase activity associated with methylene blue in whole organisms was not detected in extracts; extracts were active with benzylviologen.

Gest \& Peck (1955) and Peck \& Gest (1957a) showed with different strains of Escherichia coli that the presence of formate dehydrogenase (benzylviologen) is essential for hydrogenlyase activity. The presence of both these activities in Sarcina ventriculi means that hydrogen formation in this organism could also be explained by this hypothesis. To date, $S$. ventriculi is the only organism outside the coliform group which has been shown to possess hydrogenlyase activity. It is therefore of importance to the concept of Peck \& Gest that enzymic components similar to those found in coliform organisms, and deemed by these authors to be essential for enzymic activity, are also present in $S$. ventriculi.

Hydrogenase of Sarcina ventriculi was also extremely sensitive to inhibition by oxygen, although dithionite effectively annulled this inhibition. It was, however, significant that conditions which produced inactivation of hydrogenase also inactivated hydrogenlyase. With Escherichia coli a lag period was frequently observed in hydrogenlyase activity which Peck \& Gest (I957a) suggested was due to the combined effect of oxygen on formate dehydrogenase (benzylviologen) and hydrogenase. With $S$. ventriculi our results suggest that hydrogenase is the more likely site of hydrogenlyase inhibition. However, Peck \& Gest (1957a) found that the electron carrier required for coupling formate dehydrogenase (benzylviologen) with hydrogenase was also inactivated by aeration. Determination of the exact site of oxygen inhibition of the formate hydrogenlyase system in $S$. ventriculi must await the production of an active cell-free preparation.

This work was done while the authors were members of the Biochemistry Department, University of Glasgow. 


\section{REFERENCES}

Arbuthnott, J. P., Bauchop, T. \& Dawes, E. A. (1960). A clastic fission of pyruvic acid in Zymosarcina ventriculi. Biochem. J. 76, I2P.

BaUchop, T. \& Dawes, E. A. (1959). Metabolism of pyruvic and formic acids by Zymosarcina ventriculi. Biochim. biophys. Acta 36, 294.

BeIJerincK, M. W. (1905). An obligative anaerobic fermentation sarcina. Proc. Sect. Sci. K. ned. Acad. Wet. $7,580$.

BeIJerinck, M. W. (191 1). An experiment with Sarcina ventriculi. Proc. Sect. Sci. K. ned. Acad. Wet. I3, 1237.

Falkenheim, H. (1885). Über Sarcinae. Arch. exp. Path. Pharmak. 19, 339.

FisheR, H. F., Krasna, A. I. \& RitTENBERG, D. (1954). The interaction of hydrogenase with oxygen. J. biol. Chem. 209, 569.

GALE, E. F. (1939). Formic dehydrogenase of Bacterium coli: its inactivation by oxygen and its protection in the bacterial cell. Biochem. J. 33, IOI2.

Gest, H. \& GibBs, M. (1952). Preparation and properties of cell-free 'formic hydrogenlyase' from. Escherichia coli. J. Bact. 63, 661.

GEST, H. \& PECK, H. D., JUN. (1955). A study of the hydrogenlyase reaction with systems derived from normal and anaerogenic coli-aerogenes bacteria. J. Bact. 70, 326.

GomoRI, G. (1955). Preparation of buffers for use in enzyme studies. Meth. Enzymol. x, 138.

GoodSIR, J. (I842). History of a case in which a fluid periodically ejected from the stomach contained vegetable organisms of an undescribed form. Edinb. Med. Surg. J. 57, 430.

KLUYVER, A. J. (I93I). The Chemical Activities of Micro-organisms, p. 39, University of London Press.

LASCELles, J. (1948). Studies on formic hydrogenlyase in washed suspensions of Escherichia coli. Proc. Linn. Soc. N.S.W. 73, 430.

Milhaud, G., Aubert, J. P. \& VAN Niel, C. B. (1956). Étude de la glycolyse de Zymosarcina ventriculi. Annls Inst. Pasteur, Paris 91, 363.

Pichinoty, F. (I962). Inhibition par l'oxygène de la biosynthèse et de l'activite de l'hydrogenase et de l'hydrogenlyase chez les bactéries anaerobies facultative. Biochim. biophys. Acta 64, II I.

Pinsky, M. J. \& Stokes, J. L. (1952). Requirements for formic hydrogenlyase adaption in nonproliferating suspensions of Escherichia coli.J. Bact. 64, 151 .

PeCK, H. D., Jun. \& Gest, H. (1956). A new procedure for assay of bacterial hydrogenases. J. Bact. 7I, 70.

Peck, H. D., Jun. \& Gest, H. (1957 a). Formic dehydrogenase and the hydrogenlyase enzyme complex in coli-aerogenes bacteria. J. Bact. 73, 706.

PeCK, H. D., JUN. \& Gest, H. (I957 b). Hydrogenase of Clostridium butylicum. J. Bact. 73, 569.

SMIT, J. (1930). Die Gärungssarcine. Monographie Pflanzenforschung, Heft 14. Jena: Gustav Fisher.

StepHenson, M. \& StickLAND, L. H. (1932). Hydrogenlyases. Bacterial enzymes liberating molecular hydrogen. Biochem. J. 23, 712.

STICKLAND, L. H. (1929). The bacterial decomposition of formic acid. Biochem. J. 23, I187.

STICKLAND, L. H. (I95I). The determination of small quantities of bacteria by means of the biuret reaction J. gen. Microbiol. 5, 698.

UtTeR, M. F. \& WeRKman, C. H. (1942). Dissimilation of phosphoglyceric acid by Escherichia coli. Biochem. J. 36, 485 .

Woods, D. D. (1936). Hydrogenlyases. IV. The synthesis of formic acid by bacteria. Biochem. $J$. 30, 515 .

YUDKIN, J. (1932). Hydrogenlyases. II. Some factors concerned in the production of the enzymes Biochem J. 26, 1859. 